University of Tennessee Health Science Center UTHSC Digital Commons

$12-5-2019$

\title{
Health Status and Adults Willingness to Encounter A Provider by Telehealth
}

Jacqueline Perry

University of Tennessee Health Science Center

Follow this and additional works at: https://dc.uthsc.edu/hiimappliedresearch

Part of the Health and Medical Administration Commons, and the Health Information Technology Commons

\section{Recommended Citation}

Perry, Jacqueline, "Health Status and Adults Willingness to Encounter A Provider by Telehealth" (2019). Applied Research Projects. 68. . https://doi.org/10.21007/chp.hiim.0065

https://dc.uthsc.edu/hiimappliedresearch/68

This Research Project is brought to you for free and open access by the Department of Health Informatics and Information Management at UTHSC Digital Commons. It has been accepted for inclusion in Applied Research Projects by an authorized administrator of UTHSC Digital Commons. For more information, please contact jwelch30@uthsc.edu. 
Running head: HEALTH STATUS AND ADULTS WILLINGNESS

Health Status and Adults Willingness to Encounter A Provider by Telehealth Jacqueline Perry

University of Tennessee Health Science Center

Master of Health Informatics and Information Management

Advisor: Dr. Sajeesh Kumar

December 2019 


\section{HEALTH STATUS AND ADULTS WILLINGNESS}

\section{Acknowledgments}

The successful completion of this project would not be possible without support, help, and guidance. I would like to extend thanks to Dr. Sajeesh Kumar for giving support and guidance as an advisor. Finally, thanks to my husband and family for the love and support as I pursue my dreams. 


\title{
HEALTH STATUS AND ADULTS WILLINGNESS
}

\author{
Abstract \\ Telehealth has proven to be a growing sector providing on-demand health \\ services for consumers. A long history of development and refinement precede what we \\ now know as telehealth technology. Access to telehealth technology has become widely \\ available changing the landscape of healthcare. However, does that mean that consumers \\ desire to use the technology? How does a factor such as health status play a role in the \\ consumers' willingness to encounter a provider using telehealth as the method for \\ delivery of care? This research project aims to compare self-selected health status to \\ consumers' willingness to engage with telehealth services.
}




\section{HEALTH STATUS AND ADULTS WILLINGNESS}

\section{Table of Contents}

\section{Contents}

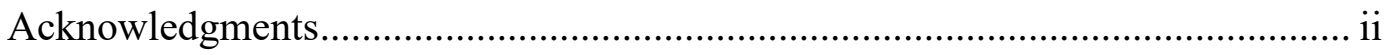

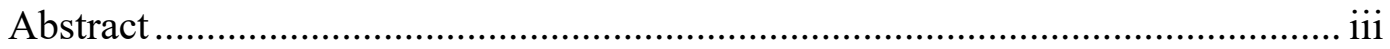

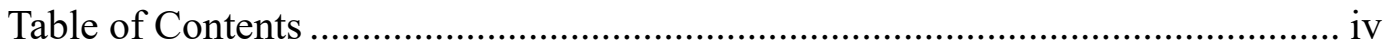

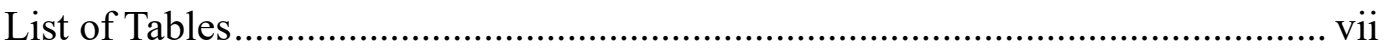

List of Figures ................................................................................... viii

Health Status and Adults Willingness to Encounter A Provider by Telehealth........1

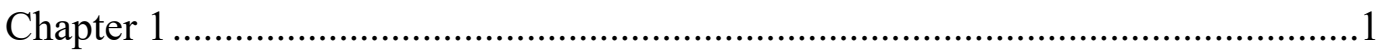

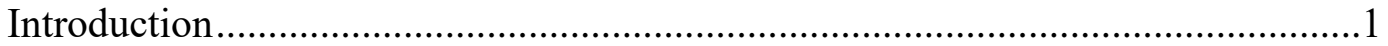

Background of the Problem ............................................................................

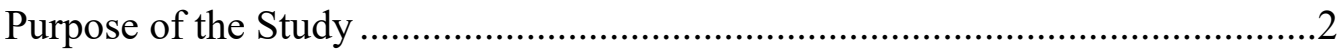

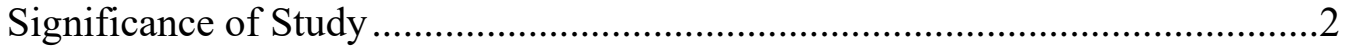

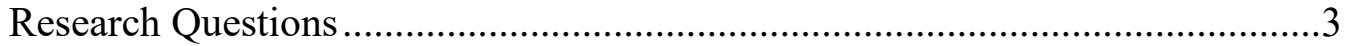

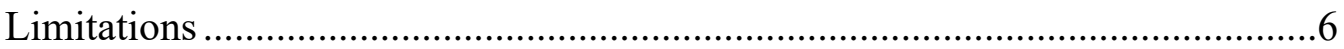

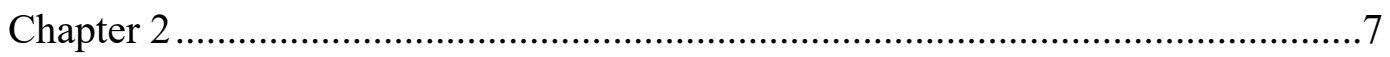

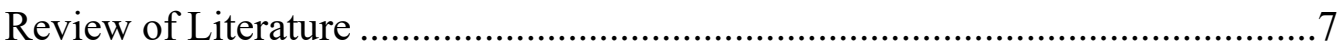

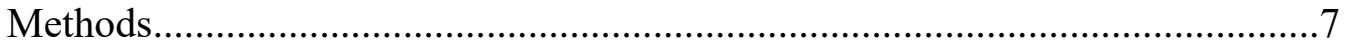

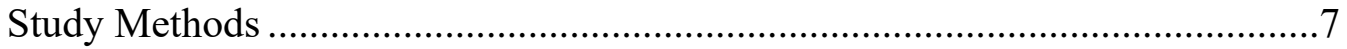

Populations Studied ............................................................................ 


\section{HEALTH STATUS AND ADULTS WILLINGNESS}

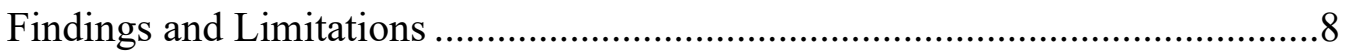

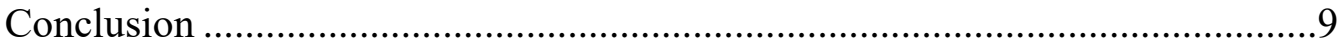

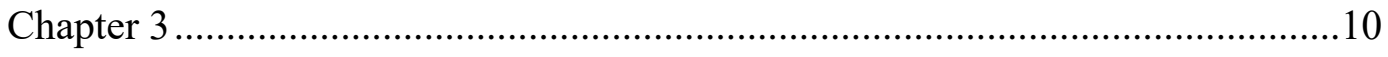

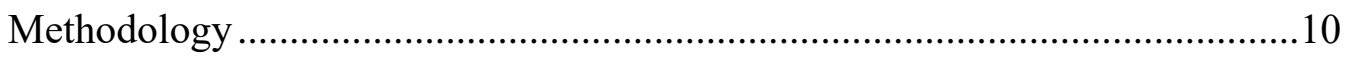

Research Design................................................................................. 10

Population Design ......................................................................... 10

Data Collection Procedures............................................................................... 11

Data Collection Instrument ................................................................ 11

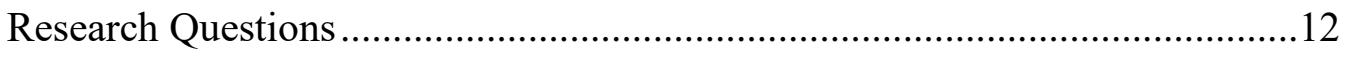

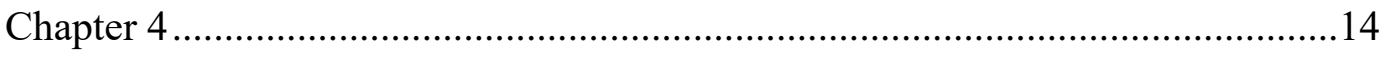

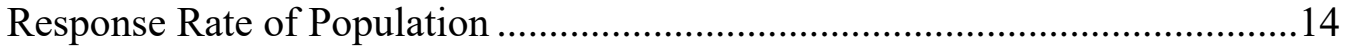

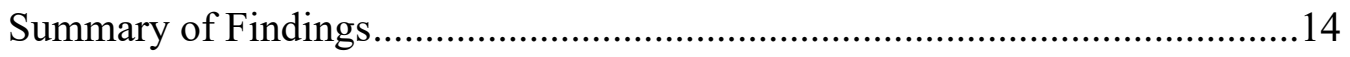

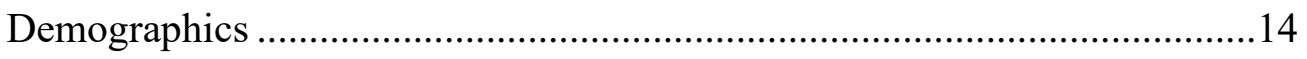

Current Behaviors .......................................................................... 14

Willingness to Utilize Telehealth Technologies .........................................15

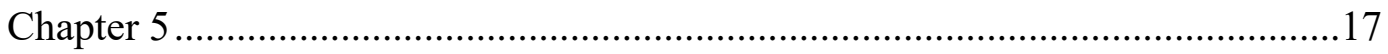

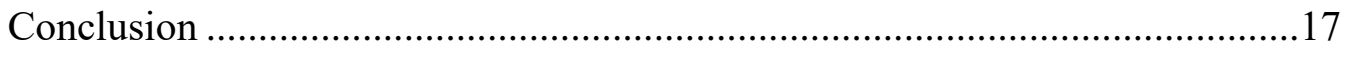

Implications and Recommendations ................................................ 18

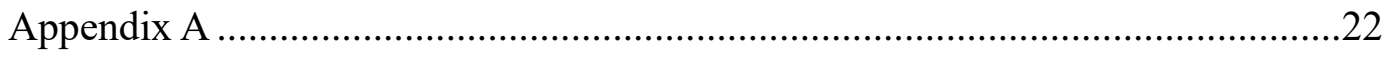

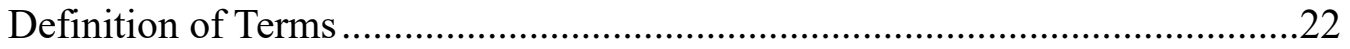




\section{HEALTH STATUS AND ADULTS WILLINGNESS}

Table 1 Review of Literature Populations Studied and Survey Methods

Table 2 Review of Literature Findings and Limitations .25

Table 3 Health Status Comparative Breakout

Appendix B .31

Figure 1. Review of Literature Search Results .31

Figure 2. Sample IRB Approved Consent Cover Letter. .32

Figure 3. IRB Approved Survey Form Sample .33

Appendix C .34

Figure 4. Gender Distribution Bar Chart..... .34

Figure 5. Age Distribution Pie Chart .34

Figure 6. Health Status Distribution Chart .35

Figure 7. Delay in Seeking Care Chart .35

Figure 8. Reason for Delay Chart..... .36

Figure 9. Willingness to See PCP Chart .36

Figure 10. Level of Interest Chart .37

Figure 11. Willingness to Switch Chart .37

Figure 12. Preferred Circumstances of Visit Chart. .38 


\section{HEALTH STATUS AND ADULTS WILLINGNESS}

\section{List of Tables}

1. Review of Literature Populations Studied and Survey Methods................... 23-24

2. Review of Literature Findings and Limitations........................................ 25-28

3. Health Status Comparative Breakout................................................... 29 


\section{HEALTH STATUS AND ADULTS WILLINGNESS}

\section{List of Figures}

1. Review of Literature Search Results........................................................ 30

2. Sample IRB Approved Consent Cover Letter............................................. 31

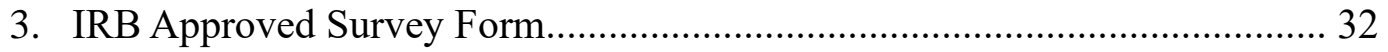

4. Gender Distribution Bar Chart................................................................ 33

5. Age Distribution Pie Chart.................................................................... 33

6. Health Status Distribution Chart............................................................. 34

7. Delay in Seeking Care Chart................................................................. 34

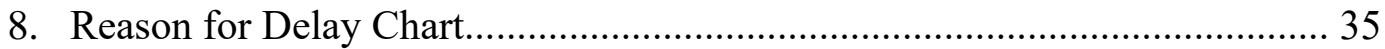

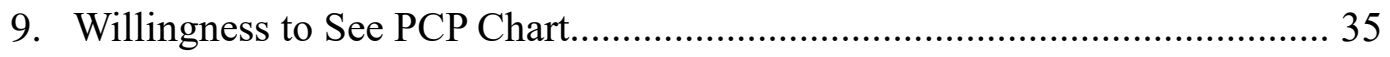

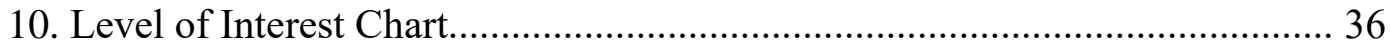

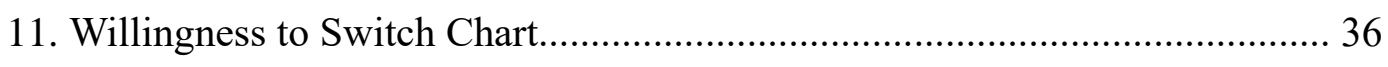

12. Preferred Circumstances of Visit Chart...................................................... 37 
HEALTH STATUS AND ADULTS WILLINGNESS

Health Status and Adults Willingness to Encounter A Provider by Telehealth

\section{Chapter 1}

\section{Introduction}

In the past decade, telehealth was forecasted for massive growth. An estimated average compound growth rate of $261 \%$ was forecasted for telehealth visits from 2015 to 2017 (Rapaport, 2018). Prior financial reports reveal that the telehealth industry has had an annual compound growth rate of $32 \%$ from 2013 to 2018. (Vockley, 2015). To understand how telehealth became this massive growing industry we must discuss the initial intersection of technology and communication. The bond of technology and communication became permanent in the year 1876 when Alexander Graham Bell patented the telephone device (Elon, 2006).

The invention of this device brought about a primary method of immediate communication. As telephone networks grew, individuals began to experience a level of connectedness that they had never previously known. NASA recognized the benefits of this technology in the 1970s and contributed to the early development of telehealth by monitoring astronaut's health conditions from a distance (Elon, 2006). NASA also applied telehealth technology by connecting rural Indians who lived on reservations to medical professionals at area hospitals (Elon, 2006). On the heels of the invention of the telephone and the additional developments by NASA, you will find the birth of telehealth or the "utilization of the telephone to reduce unnecessary office visits" (Nesbitt, 2012) as we know it today.

\section{Background of the Problem}

The technology boom of the 2000s added even more advancements in healthcare, technology, and telecommunication devices. Telehealth has equally grown and expanded to provide more healthcare services in various specialties reaching a broader population of patients. Telehealth has moved beyond standard services such as remote patient monitoring, and care management programs (InTouch, 2019). Today, telehealth is interwoven with wearable 


\section{HEALTH STATUS AND ADULTS WILLINGNESS}

technologies, artificial intelligence, and other new technologies. Although large growth estimates and technology advancements in telehealth are promising, often patients' perceptions and willingness to engage with these technologies is overlooked in research (Welch, Harvey, O’Connell, \& McElligott, 2017).

\section{Purpose of the Study}

The utilization of telehealth is dependent on many outside factors such as cost, accessibility, technology, and regulations (MDLIVE, 2018). Ultimately, the patient's decision to utilize technology as a method of receiving care is important to the success of telehealth. To understand how to facilitate the increased utilization of telehealth services we should fully understand what motivates a patient to overcome barriers and utilize new health technologies. We must begin with understanding a patient's current perception of telehealth services. Therefore, the purpose of this research project is to gain a better understanding of telehealth utilization by examining how factors like health status impact's a participant's willingness to utilize these new technologies and abandon the more familiar and traditional models of care.

\section{Significance of Study}

On the surface, the healthcare industry in the United States is considered one of the most advanced. In fact, some of the most prestigious healthcare institutions call the U.S.A. home (Haseltine, 2019). However, underneath the surface, the healthcare industry in the United States has a dark secret. The United States healthcare system is advancing towards a state of crisis and some may argue that it is already in crisis (Haseltine, 2019). Issues like increased disparities amongst various populations, healthcare costs exceeding reasonable limits, and poor health outcomes are some key factors that contribute to the poor quality of healthcare in the United States in comparison to other developed nations (Haseltine, 2019).

Telehealth has evolved to respond to the pending crisis. Telehealth can contribute to the resolution by increasing the accessibility to healthcare (California Telehealth Resource Center, 


\section{HEALTH STATUS AND ADULTS WILLINGNESS}

2017). It also can close disparities by connecting patients to providers remotely. Telehealth can contribute by reducing the time and financial cost of getting treatment, and it can aid in better health outcomes by being a quick and efficient resource for care (CTRC, 2017). The performance of this research project is significant because it will do more than just reinforce the conversation around the need and want of telehealth services. It will also display key factors that motivate individuals to engage in telehealth services, shed light on areas of opportunity for future developments, and encourage a more user-centric design methodology for the future.

\section{Research Questions}

This research project was created with an objective to discover the response to the following research question: Is health status a determinant that has an influence on a population's willingness to engage with telehealth technology? The research survey was constructed with this question in mind. The survey in total is composed of nine questions with two demographic questions, one question identifying health status, followed by six questions related to the respondent's willingness to engage with telehealth. The question types range from single choice, yes or no, and multiple-choice. The selected survey questions are listed as follows:

1) What is your gender?

Male

Female

2) What is your age?

Under 18

18-24 years old

25-34 years old

35-44 years old 
HEALTH STATUS AND ADULTS WILLINGNESS

$\square$ 45-54 years old

$\square 55$ and older

3) Please select the best statement that reflects your current health status?

Poor Health

Moderate Health

Good Health

Best Health

4) Have you ever delayed in seeking care from a doctor or nurse for a health problem?

Yes, I have delayed

No, I have not delayed

5) If you selected yes to the question above, please select the primary reason for delay:

$\square$ It cost too much.

It takes too long to see a doctor or nurse.

I thought the problem would go away on its own.

I was too busy.

6) Are you willing to see a doctor for a visit using video conference technology (i.e. Facetime)?
$\square$ Yes
$\square$ No

7) Please rate your level of interest in seeing your primary care physician via video visit?

Not at All Interested

Not Very Interested 


\section{HEALTH STATUS AND ADULTS WILLINGNESS}

Somewhat Interested

Very Interested

8) Would you be willing to switch to a primary care physician who offered office visits via video?

$\square$ I'm Not at All Willing $\quad \square$ I Am Willing

9) Please select all applicable circumstances that you would prefer an online video visit with a doctor.

Managing my Chronic Illness

After Surgery or a Hospital Stay

Prescription Renewals

Birth Control

Addressing a Common Illness (i.e. Cold, Flu) 
HEALTH STATUS AND ADULTS WILLINGNESS

\section{Limitations}

Within the development of this research limitations were identified that can impact the potential weakness of the project. During the review of literature process, a limited number of relevant articles were identified that connected with the research subject, this presented a research gap in information that created a limited view of available research related to the subject matter. Financial constraints limited the ability of the researcher to conduct the survey in multiple in-person settings in multiple locations. This project was limited in that it was conducted in a small geographic zip code, therefore the population who participated in the survey may be partial to that geographic area. Due to the setting where the surveys were distributed the likelihood of encountering participants who have "Poor" health was low, therefore the participant sample may not reflect all possible health status groups evenly. Surveys were distributed by physical paper only, thus limiting responses to individuals personally approached by the principal investigator. The span of time for the distribution and collection of the survey consisted of one month or 30 days, this limited the number of surveys that could be distributed and collected. This limited-time span for the distribution and collection of surveys also presents as a limitation due to the reduced sample size. Therefore, the generalizability of the survey results to a larger population is not recommended. 
HEALTH STATUS AND ADULTS WILLINGNESS

\section{Chapter 2}

\section{Review of Literature}

The purpose of this chapter is to present a review of the literature. The review of literature discovers available literature that is currently published and related to telehealth. The articles reviewed will be related to consumer's health status, and their current perception and willingness to engage with telehealth technologies. The review of the literature will cover how the articles were selected and what was gleaned from the articles discovered. The review of the literature chapter is broken down into sections covering the methodology, study methods, and summary.

\section{Methods}

To find academic articles relevant to the topic of discussion, inquiries were conducted within the PubMed database. The following keywords, and phrases were used to produce results for each query: "Health Status and Patient Preference for Telehealth", and "Patient Perceptions of Telehealth". To ensure the most relevant results were revealed during the searches the following limiters were applied ${ }^{1}$ :

- academic research articles

- academic articles published within the last five years

- academic articles that were written in the English language

- academic articles that were written about human subjects age 19 and older

- academic articles that were free of cost, fully accessible and available for download

\section{Study Methods}

The results of the application of the keyword search terms and limiters rendered a small sample of articles as displayed in Figure 1. Further review reduced the number of eligible articles

\footnotetext{
${ }^{1}$ See Figure 1 for a diagram of the selection process for articles included in the review of literature.
} 


\section{HEALTH STATUS AND ADULTS WILLINGNESS}

to five. Amongst the five eligible articles the method selected for gathering information from the participants ranged, but all methods recognized in the articles involved some form of direct contact with the participant. The study conducted by Lee, Greenfield, and Pappas utilized semistructured interviews that were recorded and later transcribed (2018). The semi-structured interviews were a common method and observed in three additional eligible articles. The study by Powell, Henstenburg, Cooper, Hollander, and Rising utilized survey questionnaires by telephone as their method to collect data from the participants (2017).

\section{Populations Studied}

Each eligible article clearly stated that the population they desired to survey, or interview only included participants who were 18 years of age or older. The locations where the participant populations were sourced from ranged amongst the studies. The study by Lee, Greenfield, and Pappas indicated their participants were sourced from the local telehealth team's patient database (2018). The studies conducted by Valikodath et al., and Gardner et al., obtained participants by recruiting from large academic medical centers. Uniquely, the study by Bradford, Caffery, and Smith recruited participants by approaching passerby's in a few local public areas in three different towns (2015).

\section{Findings and Limitations}

Two of the five eligible study's findings revealed that the participants were pleased with using the telehealth technology and expressed an interest in continuing to use telehealth versus the traditional model of care (Lee et al., 2018 \& Powell et al., 2017). Notably, the study conducted by Valikodath et al. revealed findings that, "Patients had decreased odds of willingness if they valued the patient-physician relationship or had a longer duration of disease. Patients had increased odds of willingness if they perceived increased convenience or had more systemic comorbidities" (2017). All five of the eligible studies listed in the review of literature declared limitations to the research. The prevalent limitation recognized included participants 


\section{HEALTH STATUS AND ADULTS WILLINGNESS}

having a more positive view of telehealth due to a prior history with telehealth technologies (Lee et al., 2018; Powell et al., 2017; Bradford et al., 2015). Additional limitations include, sampling bias, lack of timely interview sequence, and lack of generalizability to a larger population. Additional detailed information about study methods, populations studied, findings and limitations can be reviewed in Tables 1 and 2.

\section{Conclusion}

The articles considered in this literature review concluded that the success of telehealth is highly dependent on the participant's willingness to engage the technology and be interactive in the experience. Participants who are willing to utilize telehealth see it as an enhancement of their quality of life (Lee et al., 2018). Some of the deciding factors in choosing telehealth over the traditional model of care include increased convenience, communication, and privacy (Powell et al., 2017). An additional conclusion stated, 'Patients' attitudes are influenced by their health and perceptions, but not by their demographics (Valikodath et al., 2017). Telehealth is a universal way to deliver care to individuals who need and are receptive to telehealth technology. More importantly, an individual's health status could potentially play a large role in the level of receptiveness towards telehealth. 
HEALTH STATUS AND ADULTS WILLINGNESS

\section{Chapter 3}

\section{Methodology}

This chapter will reveal the type of research design method used to conduct the applied research project. Information regarding the population selected, data collection methods, and the instrument of measurement will be discussed in detail to add context to the results extracted from the research that was conducted.

\section{Research Design}

The research design that was utilized is categorized as a descriptive research method. This method proved to be the best method to capture insight from the population being researched and describe their behavioral choices and the rationale behind their level of willingness regarding telehealth utilization. The descriptive research method allowed for increased simplicity in capturing responses in an informal way. Also, the descriptive research method allowed the participants a level of privacy to answer questions with minimal oversight or interference from the principal investigator.

\section{Population Design}

The population selected for this study consisted of adults aged 18 years or older with the capacity to read and write in the English language. This population was picked due to their ability to make their own health care decisions regarding the type and method of care received. The population did not have to be local to the area where the research was conducted to limit any bias in the population. 
HEALTH STATUS AND ADULTS WILLINGNESS

\section{Data Collection Procedures}

Informed consent was presented to the participant as a cover letter in conjunction with the survey approved by the IRB ${ }^{2}$. Potential participants were approached at the local community center over a thirty-day time span. Each survey was individually distributed to eligible participants. Participants who agreed to participate and met the eligibility criteria were allotted a 15-minute time frame to complete the nine-question survey after the initial approach. Participants were encouraged to answer each applicable question on the survey form. Each survey that was completed was assigned a random eight-digit survey identification number generated within Microsoft Excel. All data collected was manually entered in the Excel spreadsheet to $\log$ the responses for future analysis. A quality check was performed to ensure accuracy in the entry of the survey responses approximately one week after all data was entered in the Excel spreadsheet.

\section{Data Collection Instrument}

The data collection instrument consisted of a printed double-sided single page paper survey. Each question on the survey was close-ended or multiple choice. The survey was nine questions total and was comprised of two demographic questions followed by seven questions that were related to the participant's health status, past health care experience, and their willingness to engage with telehealth services ${ }^{3}$.

\footnotetext{
${ }^{2}$ See Figure 2 for an excerpt of the IRB approved cover letter.

${ }^{3}$ See Figure 3 for an excerpt of the IRB approved survey.
} 


\section{HEALTH STATUS AND ADULTS WILLINGNESS}

\section{Research Questions}

The research was conducted to examine if health status is a determinant that has an influence on a population's willingness to engage with telehealth technology. The questions selected for the survey were influenced by prior research studies conducted in the fields of health services research, healthcare disparities research, and telehealth/e-medicine research. The research theme is noted in the following list of each survey question and the rationale behind each question listed.

1. What is your gender?

Rationale: Demographic Impact

2. What is your age?

Rationale: Demographic Impact

3. Please select the best statement that reflects your current health status Rationale: Health Status Classification

4. Have you ever delayed in seeking care from a doctor or nurse for a health problem? Rationale: Prior medical decisions

5. If you selected yes to the question above, please select the primary reason for delay: Rationale: Prior medical decision explanation

6. Are you willing to see a doctor for a visit using video conference technology (i.e. Facetime)?

Rationale: Utilization willingness

7. Please rate your level of interest in seeing your primary care physician via video visit?

Rationale: Utilization willingness with someone familiar

8. Would you be willing to switch to a primary care physician who offered office visits via video? 


\section{HEALTH STATUS AND ADULTS WILLINGNESS}

Rationale: Utilization willingness with someone new

9. Please select all applicable circumstances that you would prefer an online video visit with a doctor.

Rationale: Circumstances that utilization is likely 
HEALTH STATUS AND ADULTS WILLINGNESS

\section{Chapter 4}

\section{Response Rate of Population}

Paper surveys were made available to the population over a thirty-day time span broken up into weekly increments spanning from Monday to Sunday. Over the thirty-day time period, 56 individuals were approached and asked for their participation. Of the 56 potential participants, 50 agreed to complete a survey. The remaining six who opted out of participation communicated reasons such as, not being familiar with the topic, and/or not having enough time as their reason for not participating. The thirty-day distribution of paper surveys yielded a response rate of $89.28 \%$.

\section{Summary of Findings \\ Demographics}

The survey results rendered a unique view into the participant population, its demographic features and overall feelings towards telehealth technologies. From the results, 54\% of the participants were male the remaining $46 \%$ were female. All age groups were represented in the survey results. Participants who selected the "25-34 years" age range made up 50\% of the total responses, followed by the " $35-44$ years" age range making up $20 \%$ of the total population. Most participants (66\%) selected "Good" or "Best" as their self-rated health status, followed by participants who selected "Moderate" making up 30\%, and "Poor" making up 4\% of the participant responses ${ }^{4}$.

\section{Current Behaviors}

Overwhelmingly, most participants have at some point delayed in seeking health care when they needed it. Notably, the participants who selected the health status of "Good" and

\footnotetext{
${ }^{4}$ For additional information about the demographic and health status responses of the participants see Figures 4-6.
} 


\section{HEALTH STATUS AND ADULTS WILLINGNESS}

"Moderate" had more participants who have delayed in seeking care versus those who have not.

This could be indicative of increased tolerance for risk due to feeling somewhat healthy. The leading reasons participants delayed in seeking care included, "thinking the health issue would resolve itself on its own" (48\%) followed by the "cost of seeking care being too high" $(26 \%)^{5}$. Understanding the participant's demographics and feelings toward the current health care model will assist in making sense of their willingness to engage with telehealth services.

\section{Willingness to Utilize Telehealth Technologies}

A multi-angle approach was used to measure the participant's willingness to utilize telehealth technologies. The first angle examined the participant's willingness to see a doctor using telehealth video conference technology. The results revealed that $70 \%$ of the participants would be willing to see a doctor using this method. The second angle examined the participant's willingness to see their own primary care provider using telehealth video conference technology. Almost $60 \%$ of the participants indicated they were "Somewhat Interested" in accessing their own primary care provider with this method. The next angle examined the participant's willingness to switch to a primary care provider who would offer telehealth video conference technology. The results revealed that $64 \%$ of the participants were willing to switch their primary care provider to a provider who offers access to telehealth video conference technology. The health status makeup of the participants who responded positively to the willingness questions consisted of participants who indicated a health status of "Good", "Moderate" and "Best"6. Finally, the participants were asked under what circumstances would they prefer an online video visit. Amongst the five choices, most participants selected "Prescription Renewals" and

\footnotetext{
${ }^{5}$ For additional information about the delay in seeking care responses of the participants see Figures 7-8.

${ }^{6}$ For additional information about the willingness to utilize and preferences of the participants see Figures 9-12 and Table 3.
} 


\section{HEALTH STATUS AND ADULTS WILLINGNESS}

"Addressing a Common Illness" as the top two ideal circumstances to interact with a provider using telehealth technology. 


\section{HEALTH STATUS AND ADULTS WILLINGNESS}

\section{Chapter 5}

\section{Conclusion}

The results gleaned from the applied research project support similar conclusions drawn from other research studies conducted. The research project results showed that participants are willing to put off seeking care if they feel the health issue is not serious enough or the barrier of cost is too high. This disposition is noted across all health statuses reported in the data. Specifically, participants who selected health statuses that reflect a healthy disposition appear to have a higher tolerance of risk in delaying healthcare versus participants who selected health statuses that reflect a moderate to poor disposition. The issue of choosing healthcare vs. cost is found in an abundance of literature as the U.S. healthcare system is one of the most expensive to receive care from (Haseltine, 2019).

The results of the research project also support that participants are receptive to telehealth services with an existing or new provider. Other research supports the observation of participant's increased receptiveness by its findings that confirmed increased practicability or convenience in the experience of the participant vastly improved the odds of willingness (Valikodath et al., 2017). Furthermore, participants from the research project were willing to engage with more complex forms of technology to access care from a distance. To support this conclusion a research article by Gardner et al. stated, "Interest in the service, once offered, is highly dependent on the patient's willingness and confidence to co-create the experience obtaining and setting up the components required for a video appointment" (2015). In conclusion, the results of the research study help us to appreciate that the average participant with a "Moderate" to "Good" health status has more interest and willingness to use telehealth with a key focus on receiving common health care services that require minimal interaction with a health care provider versus participants who selected "Poor" as their health status of choice. 


\section{HEALTH STATUS AND ADULTS WILLINGNESS}

\section{Implications and Recommendations}

The results implicate that telehealth services are wanted by persons from a variety of age groups, health statuses, and genders. The health status of a population could be a key indicator to gauge the population's willingness to utilize telehealth services. This is reassuring to the telehealth community as there is a demand for what is being supplied to the health care consumer. While this is reassuring, it comes with a caveat. Participants from the research study shared the most interest in services that could be delivered with minimal interaction from a provider. The trust of the consumer comes into question when the utilization of telehealth services involves complex office visits. There is an opportunity to build trust with the consumer and educate them on the ability of telehealth services to be comparable to the traditional inperson care even in complex care situations. In the future, the topic of this research paper could be expounded upon with a wider population that could be generalized to the overall U.S. consumer. In addition, future research could be performed on consumer's perception of the usability of one telehealth technology platform versus another thus shaping how platforms are designed with the user in mind. 
HEALTH STATUS AND ADULTS WILLINGNESS

References

California Telehealth Resource Center. (2017). Why are Telemedicine and Telehealth so Important in Our Healthcare System? Retrieved from http://www.caltrc.org/telehealth/why-are$\underline{\text { telemedicine-and-telehealth-so-important-in-our-healthcare-system/ }}$

Bradford, N. K., Caffery, L. J., \& Smith, A. C. (2015). Awareness, experiences and perceptions of telehealth in a rural Queensland community. BMC Health Services Research, 15(1). DOI: $10.1186 / \mathrm{s} 12913-015-1094-7$

Elon University. (2006). Imagining the Internet, A History and Forecast:1870's-1940's- Telephone.

Retrieved from https://www.elon.edu/e-web/predictions/150/1870.xhtml

Gardner, M. R., Jenkins, S. M., Oneil, D. A., Wood, D. L., Spurrier, B. R., \& Pruthi, S. (2015).

Perceptions of Video-Based Appointments from the Patient's Home: A Patient

Survey. Telemedicine and e-Health, 21(4), 281-285. DOI: 10.1089/tmj.2014.0037

Haseltine, W. A. (2019, July 24). Unlocking Solutions to America's Healthcare Crisis. Retrieved from https://www.forbes.com/sites/williamhaseltine/2019/07/24/unlocking-solutions-toamericas-healthcare-crisis/\#583100214c89

health status. (n.d.) Medical Dictionary for the Health Professions and Nursing. (2012). Retrieved from https://medical-dictionary.thefreedictionary.com/health+status

InTouch Health. (2019, May 30). What's Driving Telehealth Growth in 2019. Retrieved from https://intouchhealth.com/whats-driving-telehealth-growth-in-2019/

Kaiser Family Foundation. (2012, November). Disparities in Health and Health Care: Five Key

Questions and Answers. Retrieved from https://www.pcpcc.org/resource/disparities-health-andhealth-care-five-key-questions-and-answers

Lee, P. A., Greenfield, G., \& Pappas, Y. (2018). Patients' perception of using telehealth for type 2 diabetes management: a phenomenological study. BMC Health Services Research, 18(1). DOI: 10.1186/s12913-018-3353-X 


\section{HEALTH STATUS AND ADULTS WILLINGNESS}

Lexico. (2019, January). Utilization: Definition of Utilization by Lexico. Retrieved from

https://www.lexico.com/en/definition/utilization

MDLIVE. (2018). Driving Telehealth Utilization to Maximum Value for Organizations. Retrieved from https://www.mdlive.com/wp-content/uploads/2018/03/MDLIVE_Telehealth-

$\underline{\text { Utilization_Whitepaper.pdf }}$

Nesbitt, T. S. (2012). The role of telehealth in an evolving health care environment: workshop summary. Washington, DC: National Academies Press. Retrieved from https://www.ncbi.nlm.nih.gov/books/NBK207141/

Powell, R. E., Henstenburg, J. M., Cooper, G., Hollander, J. E., \& Rising, K. L. (2017). Patient Perceptions of Telehealth Primary Care Video Visits. The Annals of Family Medicine, 15(3), 225-229. DOI: 10.1370/afm.2095

Rae, M., \& Cox, C. (2018, October 3). More employers are paying for telemedicine, but enrollee take-up has been relatively low. Retrieved from https://www.healthsystemtracker.org/brief/moreemployers-are-paying-for-telemedicine-but-enrollee-take-up-has-been-relatively-low/ Kaiser Family Foundation

Rapaport, L. (2018, December 11). Telemedicine surging in the U.S. but still uncommon. Retrieved from https://www.washingtonpost.com/national/health-science/telemedicine-grows-in-the-usbut-it-is-still-uncommon/2018/12/07/8bc86192-f31b-11e8-80d0$\underline{\text { f7e1948d55f4_story.html?noredirect }=\text { on \&utm term }=.8 \text { bdbca } 7255 \mathrm{f3}}$

Valikodath, N. G., Leveque, T. K., Wang, S. Y., Lee, P. P., Newman-Casey, P. A., Hansen, S. O., \& Woodward, M. A. (2017). Patient Attitudes Toward Telemedicine for Diabetic Retinopathy. Telemedicine and e-Health, 23(3), 205-212. DOI: 10.1089/tmj.2016.0108 Vockley, M. (2015). The Rise of Telehealth: 'Triple Aim,' Innovative Technology, and Popular Demand Are Spearheading New Models of Health and Wellness Care. Biomedical Instrumentation \& Technology, 49(5), 306-320. DOI: 10.2345/0899-8205-49.5.306 


\section{HEALTH STATUS AND ADULTS WILLINGNESS}

Welch, B. M., Harvey, J., O’Connell, N. S., \& McElligott, J. T. (2017). Patient preferences for direct-to-consumer telemedicine services: a nationwide survey. BMC Health Services

Research, 17(1). DOI: 10.1186/s12913-017-2744-8

Wilson, J. (2015, March 3). NASA History Overview. Retrieved from

https://www.nasa.gov/content/nasa-history-overview 
HEALTH STATUS AND ADULTS WILLINGNESS

\section{Appendix A}

\section{Definition of Terms}

To clarify terminology and acronyms within this research project the following list of definitions is provided below:

1. Telemedicine- "The remote delivery of clinical information using telecommunications technology" (Vockley, 2015).

2. Telehealth-"The use of electronic information and telecommunications technologies to support long-distance clinical healthcare, patient and professional health-related education public health and health administration" (Vockley, 2015).

3. NASA-acronym for the National Aeronautics and Space Administration (Wilson, 2015)

4. Utilization-the action of making practical and effective use of something (Lexico, 2019).

5. Disparities-a higher burden of illness, injury, disability, or mortality by one group relative to another (Kaiser Family Foundation, 2012)

6. Health Status- The level of health of an individual person, a group or a population as assessed by that individual or by objective measures (health status, n.d.). 
HEALTH STATUS AND ADULTS WILLINGNESS

Table 1 Review of Literature Populations Studied and Survey Methods

\begin{tabular}{|c|c|c|}
\hline Article Title and DOI & Populations Studied & Survey Methods \\
\hline $\begin{array}{l}\text { Patients' perception of using } \\
\text { telehealth for type } 2 \text { diabetes } \\
\text { management: a } \\
\text { phenomenological study. } \\
\text { DOI: } 10.1186 / \text { s } 12913-018- \\
\text { 3353-x. }\end{array}$ & $\begin{array}{l}\text { Participants were extracted } \\
\text { from Newham telehealth } \\
\text { team's patient database. } \\
\text { Study inclusion criteria } \\
\text { include: adults } \geq 18 \text { years of } \\
\text { age with a formal diagnosis } \\
\text { of type } 2 \text { diabetes, have } \\
\text { received or are receiving } \\
\text { telehealth care for type } 2 \\
\text { diabetes, speak English } \\
\text { fluently, and are able to } \\
\text { provide informed consent to } \\
\text { take part in the study. }\end{array}$ & $\begin{array}{l}\text { Semi-structured interviews } \\
\text { were conducted and recorded. } \\
\text { The interviews were } \\
\text { transcribed verbatim and the } \\
\text { analysis was guided by the } \\
\text { phenomenological analysis } \\
\text { approach. }\end{array}$ \\
\hline $\begin{array}{l}\text { Patient Perceptions of } \\
\text { Telehealth Primary Care } \\
\text { Video Visits. } \\
\text { DOI: } 10.1370 / \text { afm. } 2095 .\end{array}$ & $\begin{array}{l}\text { All patients } 18 \text { years old or } \\
\text { older who had a video visit } \\
\text { with their existing primary } \\
\text { care physician were eligible } \\
\text { for inclusion. }\end{array}$ & $\begin{array}{l}\text { We conducted individual } \\
\text { semi-structured interviews } \\
\text { with patients who had } \\
\text { completed a video visit with } \\
\text { their primary care physician } \\
\text { at either the family medicine } \\
\text { or the internal medicine } \\
\text { practice at Thomas Jefferson } \\
\text { University. }\end{array}$ \\
\hline $\begin{array}{l}\text { Patient Attitudes Toward } \\
\text { Telemedicine for Diabetic } \\
\text { Retinopathy. } \\
\text { DOI: } 10.1089 / \mathrm{tmj} .2016 .0108\end{array}$ & $\begin{array}{l}\text { Participants were recruited } \\
\text { from the Duke University } \\
\text { Medical Center and from the } \\
\text { Durham Veterans Affairs } \\
\text { primary care and endocrine } \\
\text { clinics. Consecutive adults } \\
\text { with diabetes from a } \\
\text { convenience sample of } \\
\text { patients were recruited from } \\
\text { these centers. }\end{array}$ & $\begin{array}{l}\text { Two research assistants } \\
\text { conducted all interviews in } \\
\text { person with the participants. }\end{array}$ \\
\hline $\begin{array}{l}\text { Awareness, experiences and } \\
\text { perceptions of telehealth in a } \\
\text { rural Queensland community. } \\
\text { DOI: } 10.1186 / \mathrm{s} 12913-015- \\
1094-7\end{array}$ & $\begin{array}{l}\text { A convenience sample of } \\
\text { participants was recruited } \\
\text { from local public areas (main } \\
\text { street and shopping mall) in } \\
\text { all three towns. Participants } \\
\text { were required to speak } \\
\text { English, be over the age of } 18 \\
\text { years and have the capacity to } \\
\text { provide informed consent. }\end{array}$ & $\begin{array}{l}\text { Semi-structured interviews } \\
\text { were undertaken with } 47 \\
\text { participants from three rural } \\
\text { towns in the Darling Downs } \\
\text { region of Queensland. } \\
\text { Content analysis was used to } \\
\text { abstract themes and core } \\
\text { concepts from the interviews. }\end{array}$ \\
\hline $\begin{array}{l}\text { Perceptions of video-based } \\
\text { appointments from the } \\
\text { patient's home: a patient } \\
\text { survey. }\end{array}$ & $\begin{array}{l}\text { Patients seen by both primary } \\
\text { care and specialist providers } \\
\text { from a single academic } \\
\text { institution in Minnesota that }\end{array}$ & $\begin{array}{l}\text { survey questionnaire given by } \\
\text { telephone included questions } \\
\text { about estimated future visits } \\
\text { to the local institution, }\end{array}$ \\
\hline
\end{tabular}


HEALTH STATUS AND ADULTS WILLINGNESS

\begin{tabular}{|l|l|l|}
\hline DOI: 10.1089/tmj.2014.0037 & $\begin{array}{l}\text { serves primary care, } \\
\text { community, and regional } \\
\text { specialty needs. For } \\
\text { inclusion, the patients' last } \\
\text { visit was required to be } \\
\text { outpatient, under the } \\
\text { assumption that an inpatient } \\
\text { care episode aligned with } \\
\text { acuity that would not be } \\
\text { suitable for a video } \\
\text { appointment. All participants } \\
\text { and all potential participants } \\
\text { were over 18 years of age and } \\
\text { had been seen at the } \\
\text { institution between July 1, } \\
\text { 2011, and July 31, 2012. }\end{array}$ & $\begin{array}{l}\text { fatient technology ownership, } \\
\text { preference for video } \\
\text { appointments and factors } \\
\text { informing those preferences, } \\
\text { patient qualitative valuation } \\
\text { of a video appointment, and } \\
\text { fact collecting about the costs } \\
\text { of travel to be evaluated in- } \\
\text { person at the local institution }\end{array}$ \\
\hline
\end{tabular}


HEALTH STATUS AND ADULTS WILLINGNESS

Table 2 Review of Literature Findings and Limitations

\begin{tabular}{|c|c|c|}
\hline Article Title and DOI & Findings & Limitations \\
\hline $\begin{array}{l}\text { Patients' perception of using } \\
\text { telehealth for type } 2 \text { diabetes } \\
\text { management: a } \\
\text { phenomenological study. } \\
\text { DOI: } 10.1186 / \text { s } 12913-018- \\
\text { 3353-x. }\end{array}$ & $\begin{array}{l}\text { All patients asserted that they } \\
\text { were pleased with the } \\
\text { technology and many also } \\
\text { proclaimed that they could } \\
\text { not see themselves being } \\
\text { without it. Moreover, very } \\
\text { few negative views were } \\
\text { reported with respect to the } \\
\text { use of telehealth. The } \\
\text { findings of the study } \\
\text { demonstrate the feasibility of } \\
\text { telehealth monitoring at home } \\
\text { as well its potential benefits } \\
\text { in people living with type } 2 \\
\text { diabetes. Overall, the } \\
\text { evidence from this study } \\
\text { showed that telehealth has the } \\
\text { potential to enhance patient's } \\
\text { quality of life, allow them to } \\
\text { live independently at home as } \\
\text { well as help them take and be } \\
\text { in more control over their } \\
\text { own health state. It, therefore, } \\
\text { supports the use of telehealth } \\
\text { for the routine care of people } \\
\text { with type } 2 \text { diabetes. }\end{array}$ & $\begin{array}{l}\text { The sample was post-WSD } \\
\text { telehealth patients and } \\
\text { therefore those who most } \\
\text { certainly had a more } \\
\text { favorable attitude towards } \\
\text { telehealth even before their } \\
\text { participation in the study. The } \\
\text { study did not manage to } \\
\text { recruit any of those who had } \\
\text { withdrawn from a telehealth } \\
\text { intervention, it is very } \\
\text { possible that the patient } \\
\text { sample of this study is } \\
\text { skewed towards those with a } \\
\text { more optimistic view. }\end{array}$ \\
\hline $\begin{array}{l}\text { Patient Perceptions of } \\
\text { Telehealth Primary Care } \\
\text { Video Visits. } \\
\text { DOI: } 10.1370 / \mathrm{afm} .2095 \text {. }\end{array}$ & $\begin{array}{l}\text { Of } 32 \text { eligible patients, } 19 \\
\text { were successfully } \\
\text { interviewed. All patients } \\
\text { reported overall satisfaction } \\
\text { with video visits, with the } \\
\text { majority interested in } \\
\text { continuing to use video visits } \\
\text { as an alternative to in-person } \\
\text { visits. The primary benefits } \\
\text { cited were convenience and } \\
\text { decreased costs. Some } \\
\text { patients felt more comfortable } \\
\text { with video visits than office } \\
\text { visits and expressed a } \\
\text { preference for receiving } \\
\text { future serious news via video } \\
\text { visit, because they could be in } \\
\text { their own supportive } \\
\text { environment. Primary } \\
\text { concerns with video visits }\end{array}$ & $\begin{array}{l}\text { The sampling frame was } \\
\text { limited to patients within } 2 \\
\text { practices in } 1 \text { health system, } \\
\text { both successful early adopters } \\
\text { of this service. Most } \\
\text { participants had experience } \\
\text { with video conferencing, and } \\
\text { all had successful encounters, } \\
\text { so technical problems that } \\
\text { might shape patients' } \\
\text { experiences with video visits } \\
\text { (such as being unable to set } \\
\text { up a visit or not having access } \\
\text { to video technology) did not } \\
\text { arise. More, we don't know } \\
\text { how clinicians selected } \\
\text { potential participants, and } \\
\text { their selection criteria may } \\
\text { have introduced bias in the } \\
\text { population. We were unable }\end{array}$ \\
\hline
\end{tabular}




\begin{tabular}{|c|c|c|}
\hline & $\begin{array}{l}\text { were privacy, including the } \\
\text { potential for work colleagues } \\
\text { to overhear conversations, } \\
\text { and questions about the } \\
\text { ability of the clinician to } \\
\text { perform an adequate physical } \\
\text { examination. }\end{array}$ & $\begin{array}{l}\text { to contact or are missing the } \\
\text { interview data for } 41 \% \\
\text { (13/32) of the individuals } \\
\text { approached for this study, and } \\
\text { we cannot tell how this lack } \\
\text { may affect transportability of } \\
\text { findings. Additionally, while } \\
\text { efforts were made to conduct } \\
\text { the interviews as close to the } \\
\text { visit as possible, interviews } \\
\text { were conducted up to } 1 \\
\text { month later, and patients with } \\
\text { longer interview delays may } \\
\text { have had difficulties } \\
\text { remembering details of their } \\
\text { visit. In addition, } 2 \text { of the } \\
\text { authors were involved with } \\
\text { developing the telehealth } \\
\text { program at the clinic, and } 1 \text { of } \\
\text { the physician authors is in } 1 \\
\text { of the clinical practices } \\
\text { implementing this service. To } \\
\text { minimize the bias this might } \\
\text { introduce, the } 2 \text { non- } \\
\text { physician team members } \\
\text { conducted all the interviews, } \\
\text { and the group interpreted the } \\
\text { results. }\end{array}$ \\
\hline $\begin{array}{l}\text { Patient Attitudes Toward } \\
\text { Telemedicine for Diabetic } \\
\text { Retinopathy. } \\
\text { DOI: } 10.1089 / \text { tmj. } 2016.0108\end{array}$ & $\begin{array}{l}\text { Demographic factors were } \\
\text { not associated with the } \\
\text { outcomes (all } \mathrm{p}>0.05) \text {. } \\
\text { Patients had decreased odds } \\
\text { of willingness if they valued } \\
\text { the patient-physician } \\
\text { relationship (adjusted odds } \\
\text { ratio [OR] }=0.08 \text {, confidence } \\
\text { interval [CI] }=0.02-0.35 \text {, } \\
\mathrm{p}=0.001 \text { ) or had a longer } \\
\text { duration of diabetes (adjusted } \\
\text { OR=0.93, CI }=0.88-0.99, \\
\mathrm{p}=0.02 \text { ). Patients had } \\
\text { increased odds of willingness } \\
\text { if they perceived increased } \\
\text { convenience (adjusted OR= } \\
8.10, \mathrm{CI}=1.77-36.97, \mathrm{p}=0.01 \text { ) } \\
\text { or had more systemic } \\
\text { comorbidities (adjusted } \\
\text { OR=1.85, CI=1.10-3.11, } \\
\mathrm{p}=0.02 \text { ). }\end{array}$ & $\begin{array}{l}\text { All participants were patients } \\
\text { in an endocrinology or } \\
\text { primary care clinic. We did } \\
\text { not include patients outside of } \\
\text { the healthcare system. We } \\
\text { used a convenience sample } \\
\text { approach for patient } \\
\text { recruitment, which introduces } \\
\text { some potential biases. Also, a } \\
\text { low percentage of women } \\
\text { were enrolled in the study, } \\
\text { largely due to recruitment at } \\
\text { the Veterans Affairs clinics. } \\
\text { This limits the } \\
\text { generalizability of our results. } \\
\text { Self-reported ocular and } \\
\text { systemic comorbidities may } \\
\text { differ from clinical diagnoses, } \\
\text { which could potentially } \\
\text { impact their association with } \\
\text { the measured outcomes. }\end{array}$ \\
\hline
\end{tabular}




\begin{tabular}{|c|c|c|}
\hline & & $\begin{array}{l}\text { Interviewers provided } \\
\text { information about } \\
\text { telemedicine, whereas patient } \\
\text { responses were based on } \\
\text { hypothetical extrapolation, } \\
\text { not on practical experience } \\
\text { with telemedicine services. }\end{array}$ \\
\hline $\begin{array}{l}\text { Awareness, experiences and } \\
\text { perceptions of telehealth in a } \\
\text { rural Queensland community. } \\
\text { DOI: } 10.1186 / \text { s } 12913-015- \\
1094-7\end{array}$ & $\begin{array}{l}\text { Three participants were } \\
\text { healthcare providers who had } \\
\text { all previously used telehealth } \\
\text { in their clinical practice. } \\
\text { Twenty-seven }(57 \%) \\
\text { participants regularly traveled } \\
\text { to access specialist } \\
\text { healthcare. While } 28 \text { ( } 60 \%) \\
\text { participants were aware of } \\
\text { telehealth, only six ( } 13 \%) \\
\text { had used telehealth services; } \\
\text { three as patients and three as } \\
\text { healthcare providers. Major } \\
\text { themes evident included: } \\
\text { acceptance of the need to } \\
\text { travel; paternalism and } \\
\text { empowerment; and trust and } \\
\text { misconceptions. }\end{array}$ & $\begin{array}{l}\text { Only six of our participants } \\
\text { had experienced telehealth, } \\
\text { hence there may have been } \\
\text { positivity bias to the number } \\
\text { of interviewees that stated } \\
\text { they would use telehealth or } \\
\text { considered telehealth to be a } \\
\text { good idea. As a qualitative } \\
\text { study, the findings from this } \\
\text { study are not generalizable } \\
\text { beyond the sample recruited. } \\
\text { Furthermore, as a } \\
\text { convenience sample, our } \\
\text { participants expressed their } \\
\text { own views and experiences; } \\
\text { these may not be } \\
\text { representative views of the } \\
\text { whole community. }\end{array}$ \\
\hline $\begin{array}{l}\text { Perceptions of video-based } \\
\text { appointments from the } \\
\text { patient's home: a patient } \\
\text { survey. } \\
\text { DOI: } 10.1089 / \mathrm{tmj} .2014 .0037\end{array}$ & $\begin{array}{l}\text { Patient demand for video } \\
\text { appointments from their } \\
\text { homes is nascent, but a core } \\
\text { of patients whose interest } \\
\text { could be leveraged to help } \\
\text { nurture mainstream usage. } \\
\text { Interest in the service, once } \\
\text { offered, is highly dependent } \\
\text { on the patient's willingness } \\
\text { and confidence to co-create } \\
\text { the experience obtaining and } \\
\text { setting up the components } \\
\text { required for a video } \\
\text { appointment. Distance from } \\
\text { the clinic is a definite } \\
\text { motivator, but one that needs } \\
\text { to be balanced with other } \\
\text { economic costs to the patient. }\end{array}$ & $\begin{array}{l}\text { We did not attempt to balance } \\
\text { participants for age, } \\
\text { race/ethnicity, or } \\
\text { socioeconomics, and we } \\
\text { recognize that the patient } \\
\text { population from the single } \\
\text { institution may not reflect the } \\
\text { national population makeup. } \\
\text { This potentiality has } \\
\text { implications on the } \\
\text { prevalence of endpoint } \\
\text { devices and broadband } \\
\text { penetration and limits } \\
\text { generalizations that can be } \\
\text { made. This study did not seek } \\
\text { to capture patient-specific } \\
\text { economic data, which may } \\
\text { have added additional insight } \\
\text { into why participants } \\
\text { indicated an interest to pay } \\
\text { out of pocket for the services } \\
\text { or to travel for care. This } \\
\text { study did not seek access to } \\
\text { patient health data, which }\end{array}$ \\
\hline
\end{tabular}


HEALTH STATUS AND ADULTS WILLINGNESS

\begin{tabular}{|l|l|l|}
\hline & $\begin{array}{l}\text { may also have helped to add } \\
\text { insight as to how they } \\
\text { indicated interest. }\end{array}$ \\
\hline
\end{tabular}


HEALTH STATUS AND ADULTS WILLINGNESS

Table 3 Health Status Comparative Breakout

\begin{tabular}{|c|c|c|c|c|c|c|}
\hline Question & Response Options & $\begin{array}{l}\text { Moderat } \\
\text { e Health }\end{array}$ & $\begin{array}{l}\text { Good } \\
\text { Health }\end{array}$ & $\begin{array}{l}\text { Best } \\
\text { Healt } \\
\text { h }\end{array}$ & $\begin{array}{l}\text { Poor } \\
\text { Health }\end{array}$ & $\begin{array}{l}\text { Overall } \\
\text { Results }\end{array}$ \\
\hline \multicolumn{7}{|l|}{$\begin{array}{l}\text { Q1- } \\
\text { Gender }\end{array}$} \\
\hline & Male & $12 \%$ & $28 \%$ & $12 \%$ & $2 \%$ & $54 \%$ \\
\hline & Female & $18 \%$ & $26 \%$ & $0 \%$ & $2 \%$ & $46 \%$ \\
\hline \multicolumn{7}{|l|}{$\begin{array}{l}\text { Q2- Age } \\
\text { Range }\end{array}$} \\
\hline & Under 18 & $0 \%$ & $0 \%$ & $0 \%$ & $0 \%$ & $0 \%$ \\
\hline & 18-24 years old & $0 \%$ & $4 \%$ & $0 \%$ & $0 \%$ & $4 \%$ \\
\hline & 25-34 years old & $20 \%$ & $26 \%$ & $4 \%$ & $0 \%$ & $50 \%$ \\
\hline & $35-44$ years old & $2 \%$ & $14 \%$ & $4 \%$ & $0 \%$ & $20 \%$ \\
\hline & 45-54 years old & $2 \%$ & $2 \%$ & $2 \%$ & $2 \%$ & $8 \%$ \\
\hline & 55 and older & $6 \%$ & $8 \%$ & $2 \%$ & $2 \%$ & $18 \%$ \\
\hline \multicolumn{7}{|c|}{ Q4-Delayed in Seeking Care } \\
\hline & Yes, I have delayed & $22 \%$ & $32 \%$ & $6 \%$ & $2 \%$ & $62 \%$ \\
\hline & No, I have not delayed & $8 \%$ & $22 \%$ & $6 \%$ & $2 \%$ & $38 \%$ \\
\hline \multirow[t]{5}{*}{$\begin{array}{l}\text { Q5-Delay } \\
\text { Reasoning }\end{array}$} & Response Options & $\begin{array}{l}\text { Moderat } \\
\text { e Health }\end{array}$ & $\begin{array}{l}\text { Good } \\
\text { Health }\end{array}$ & $\begin{array}{l}\text { Best } \\
\text { Healt } \\
\text { h }\end{array}$ & $\begin{array}{l}\text { Poor } \\
\text { Health }\end{array}$ & $\begin{array}{l}\text { Overall } \\
\text { Results }\end{array}$ \\
\hline & It cost too much & $6 \%$ & $8 \%$ & $2 \%$ & $0 \%$ & $26 \%$ \\
\hline & $\begin{array}{l}\text { It takes too long to see a } \\
\text { doctor or nurse }\end{array}$ & $0 \%$ & $6 \%$ & $0 \%$ & $0 \%$ & $10 \%$ \\
\hline & $\begin{array}{l}\text { I thought the problem } \\
\text { would go away on its own }\end{array}$ & $12 \%$ & $12 \%$ & $4 \%$ & $2 \%$ & $48 \%$ \\
\hline & I was too busy & $4 \%$ & $6 \%$ & $0 \%$ & $0 \%$ & $16 \%$ \\
\hline \multicolumn{7}{|c|}{ Q6-Willingness to Utilize Telehealth } \\
\hline & Yes & $20 \%$ & $40 \%$ & $8 \%$ & $2 \%$ & $70 \%$ \\
\hline & No & $10 \%$ & $14 \%$ & $4 \%$ & $2 \%$ & $30 \%$ \\
\hline \multicolumn{7}{|c|}{$\begin{array}{l}\text { Q7- Interest in Seeing Familiar } \\
\text { Provider }\end{array}$} \\
\hline & Not at All Interested & $2 \%$ & $8 \%$ & $0 \%$ & $2 \%$ & $12 \%$ \\
\hline & Not Very Interested & $6 \%$ & $6 \%$ & $2 \%$ & $0 \%$ & $14 \%$ \\
\hline & Somewhat Interested & $20 \%$ & $28 \%$ & $6 \%$ & $2 \%$ & $56 \%$ \\
\hline & Very Interested & $2 \%$ & $12 \%$ & $4 \%$ & $0 \%$ & $18 \%$ \\
\hline \multicolumn{7}{|c|}{$\begin{array}{l}\text { Q8-Willingness to Switch to a New } \\
\text { Provider }\end{array}$} \\
\hline & I Am Willing & $20 \%$ & $34 \%$ & $12 \%$ & $0 \%$ & $66 \%$ \\
\hline & I'm Not at All Willing & $10 \%$ & $20 \%$ & $0 \%$ & $4 \%$ & $34 \%$ \\
\hline \multicolumn{7}{|c|}{ Q9-Circumstance of Visit } \\
\hline & $\begin{array}{l}\text { Addressing a Common } \\
\text { Illness }\end{array}$ & $8 \%$ & $19 \%$ & $3 \%$ & $1 \%$ & $31 \%$ \\
\hline
\end{tabular}


HEALTH STATUS AND ADULTS WILLINGNESS

\begin{tabular}{|l|r|r|r|r|r|}
\hline Prescription Renewals & $9 \%$ & $18 \%$ & $2 \%$ & $0 \%$ & $29 \%$ \\
\hline Birth Control & $5 \%$ & $8 \%$ & $1 \%$ & $0 \%$ & $14 \%$ \\
\hline $\begin{array}{l}\text { After Surgery/ Hospital } \\
\text { Stay }\end{array}$ & $3 \%$ & $5 \%$ & $4 \%$ & $1 \%$ & $13 \%$ \\
\hline \begin{tabular}{l} 
Chronic Illness \\
\hline
\end{tabular} & $4 \%$ & $6 \%$ & $2 \%$ & $1 \%$ & $13 \%$ \\
\hline
\end{tabular}




\section{HEALTH STATUS AND ADULTS WILLINGNESS \\ Appendix B}

Figure 1. Review of Literature Search Results

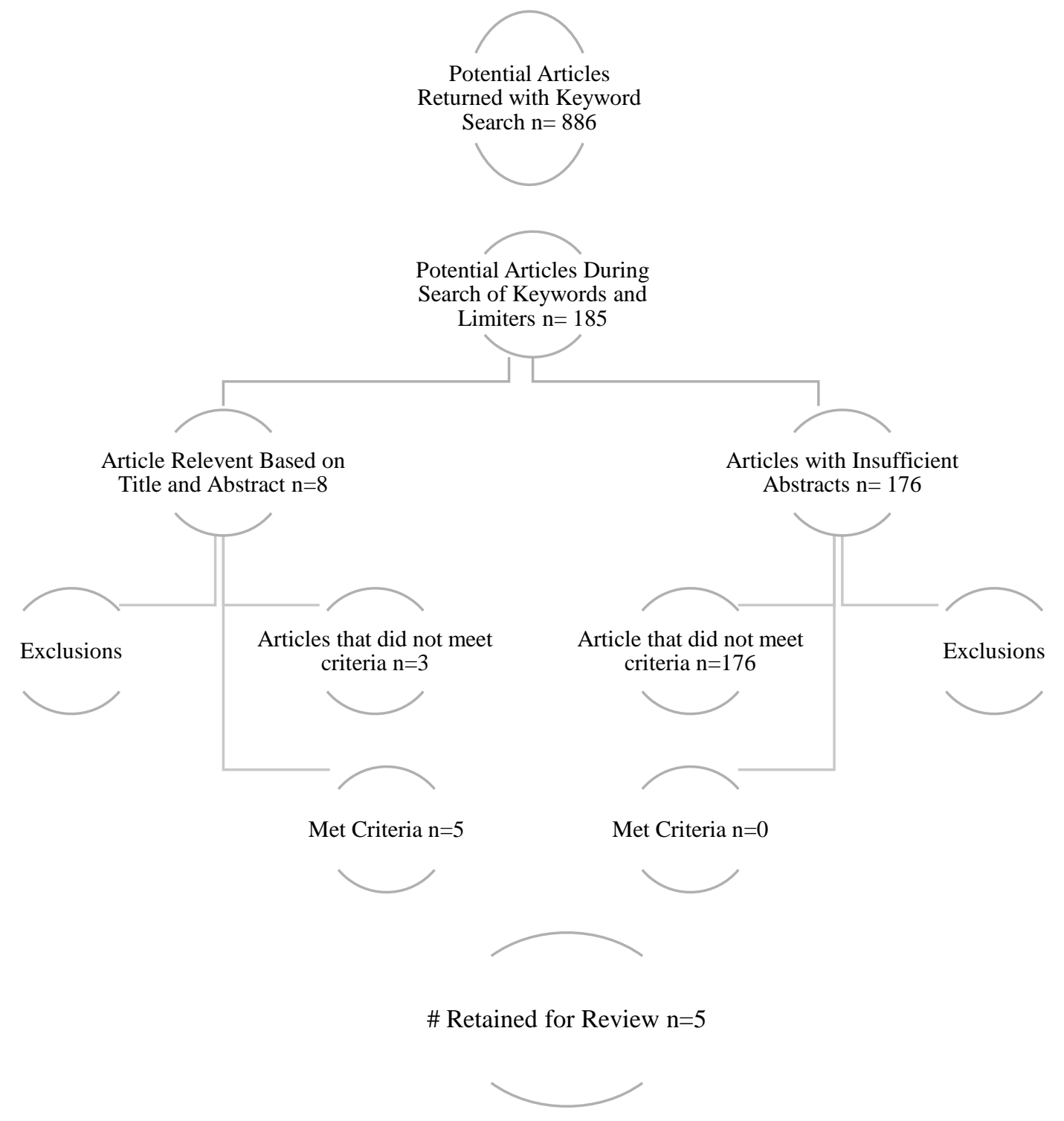




\section{HEALTH STATUS AND ADULTS WILLINGNESS}

\section{Figure 2. Sample IRB Approved Consent Cover Letter}

IRB NUMBER: 19-06763-XM

IRB APPROVAL DATE: 08/01/2019

Preparation Date: July 31st, 2019

Evaluating the Impact of Health Status on Adults Willingness to Encounter A Provider by Telehealth

Dear Participant,

You are being asked to participate in a research study conducted by Jacqueline Perry the principal investigator. Your participation will assist us in gaining insight into your perception and willingness to utilize telehealth technology. Individuals invited to participate in this study must be 18 years or older with the capacity to read and write in the English language.

If you decide to take part in this research study, you will complete a short survey. The survey consists of nine questions and will take approximately 5 minutes of your time to complete the survey. There are no further procedures required. The investigator will analyze the results.

There are no physical risks associated with this study. Every effort will be made to keep your survey responses confidential; however, this cannot be guaranteed. 
HEALTH STATUS AND ADULTS WILLINGNESS

\section{Figure 3. IRB Approved Survey Form Sample}

IRB NUMBER: 19-06763-XM IRB APPROVAL DATE: 08/01/2019

Survey \#

\section{Telehealth Participant Survey}

1) What is your gender?

$\square$ Male

$\square$ Female

2) What is your age?

$\square$ Under 18

$\square 18-24$ years old

$\square$ 25-34 years old

$\square$ 35-44 years old

$\square$ 45-54 years old

$\square 55$ and older

3) Please select the best statement that reflects your current health status?

$\square$ Poor Health

$\square$ Moderate Health

$\square$ Good Health

$\square$ Best Health

4) Have you ever delayed in seeking care from a doctor or nurse for a health problem?

$\square$ Yes, I have delayed

$\square$ No, I have not delayed 
HEALTH STATUS AND ADULTS WILLINGNESS

Appendix C

Figure 4. Gender Distribution Bar Chart

\section{Gender Distribution}

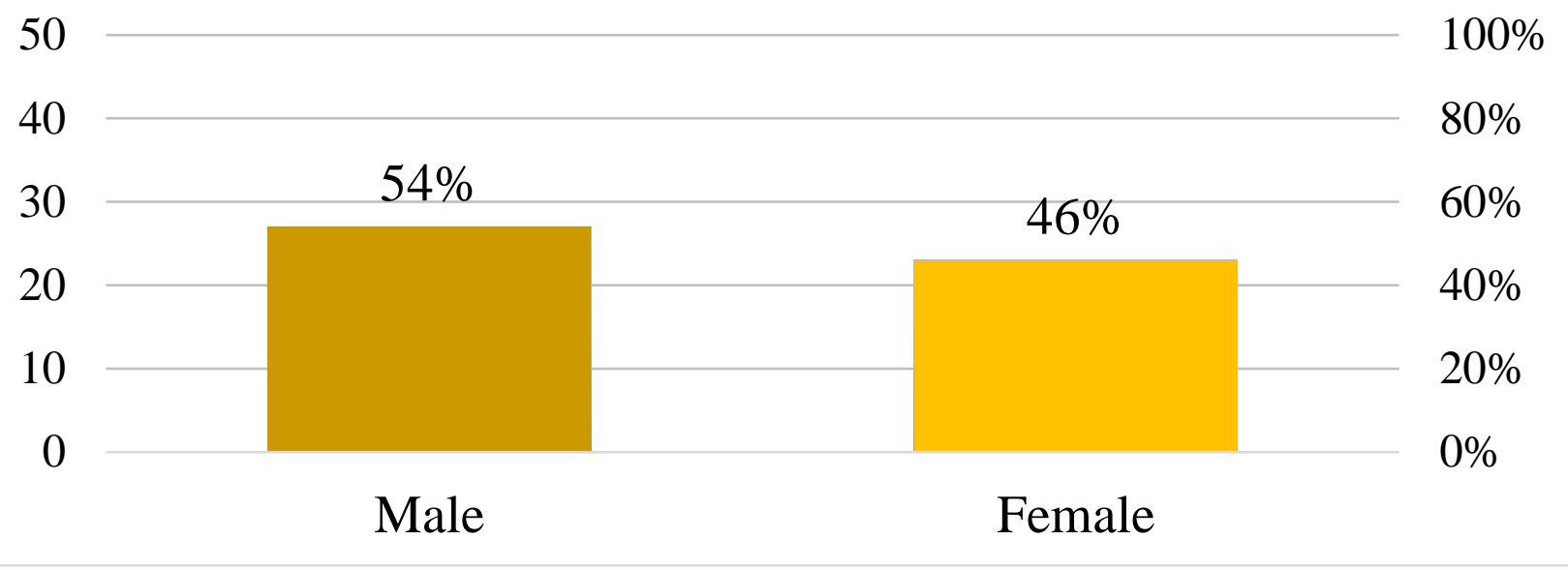

Figure 5. Age Distribution Pie Chart

\section{Age Distribution}

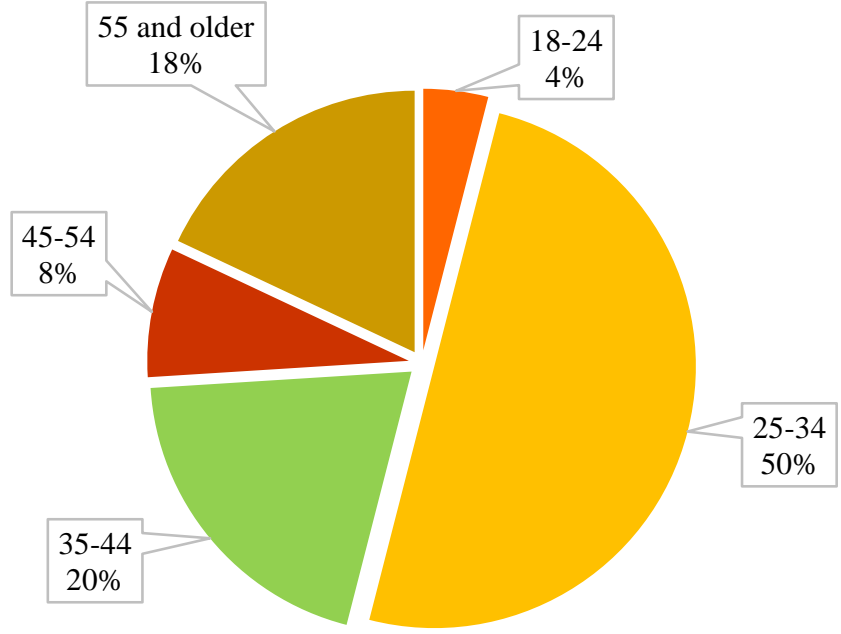

$\square 18-24 \backsim 25-34 \quad \square 35-44 \quad \square$ 45-54 $\square 55$ and older 
HEALTH STATUS AND ADULTS WILLINGNESS

Figure 6. Health Status Distribution Chart

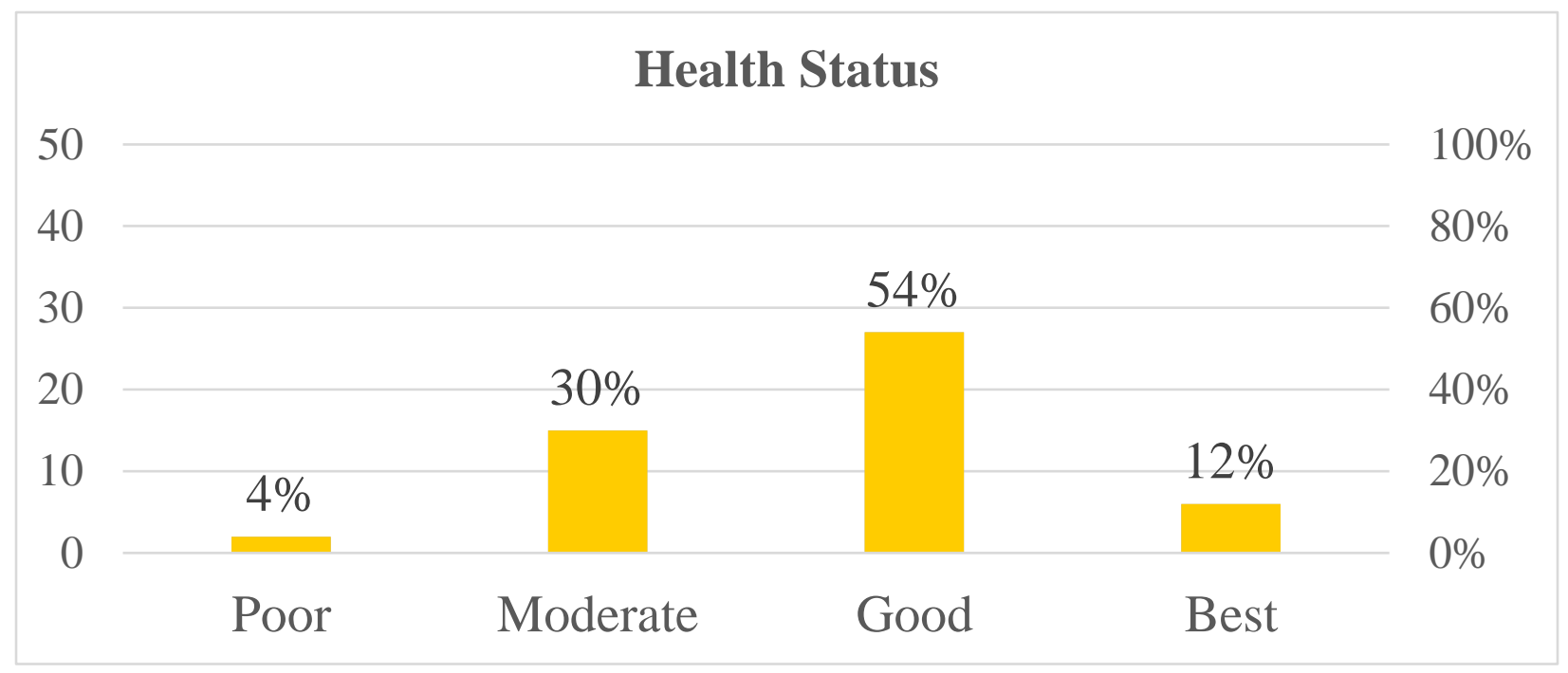

Figure 7. Delay in Seeking Care Chart

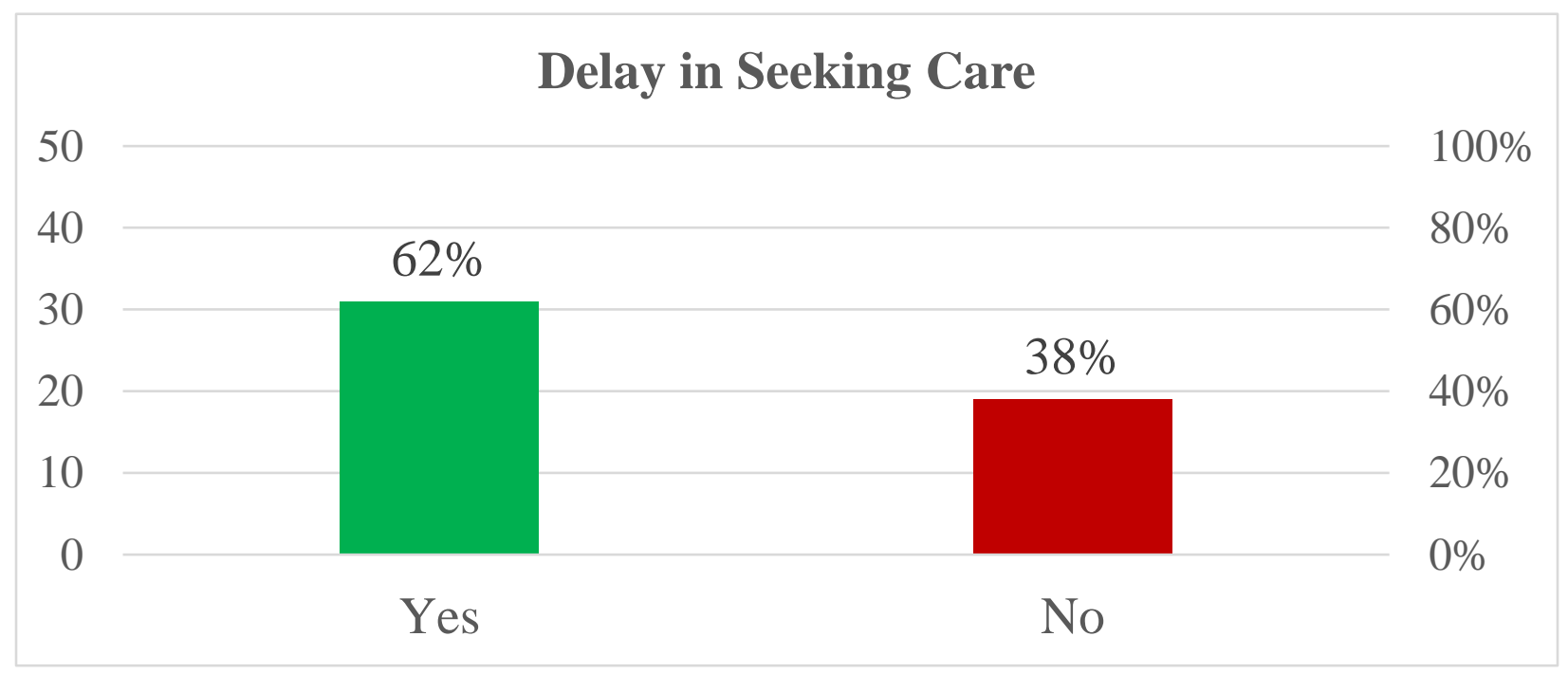


HEALTH STATUS AND ADULTS WILLINGNESS

Figure 8. Reason for Delay Chart

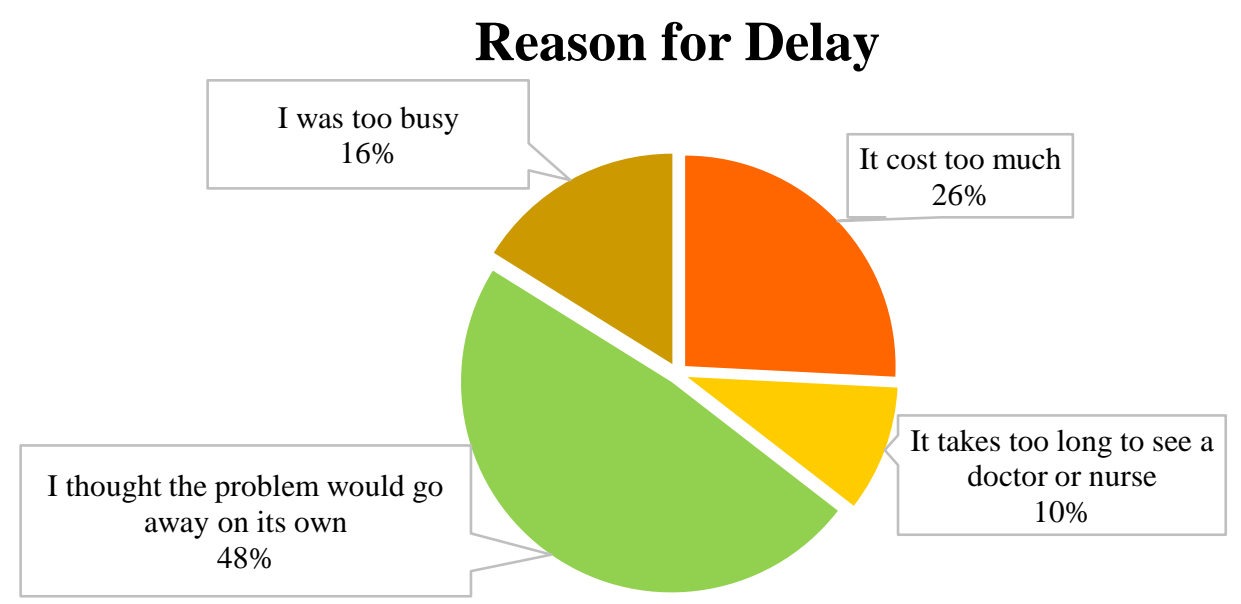

Figure 9. Willingness to See PCP Chart

\begin{tabular}{|cccc|}
\hline \multicolumn{3}{|c|}{ Willingness to See Doctor via Video } \\
\hline 50 & & & $100 \%$ \\
40 & $70 \%$ & & $80 \%$ \\
30 & & & $60 \%$ \\
20 & & $30 \%$ & $40 \%$ \\
10 & & & $20 \%$ \\
0 & & & $0 \%$ \\
\hline
\end{tabular}


HEALTH STATUS AND ADULTS WILLINGNESS

Figure 10. Level of Interest Chart

\begin{tabular}{|c|c|c|c|c|c|}
\hline Lev & el of Interest in & CP & o Visi & & \\
\hline & $20 \%$ & $40 \%$ & $60 \%$ & $80 \%$ & $100 \%$ \\
\hline Very Interested & $18 \%$ & & & & \\
\hline Somewhat Interested & & & $56 \%$ & & \\
\hline Not Very Interested & $14 \%$ & & & & \\
\hline Not at All Interested & & & & & \\
\hline & 10 & 20 & 30 & 40 & 50 \\
\hline
\end{tabular}

Figure 11. Willingness to Switch Chart

Willingness to Switch To A Provider Who Offers Telehealth

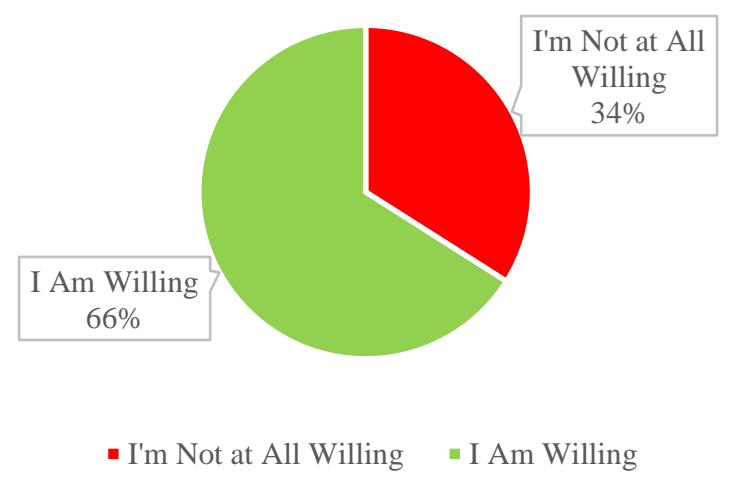


HEALTH STATUS AND ADULTS WILLINGNESS

Figure 12. Preferred Circumstances of Visit Chart

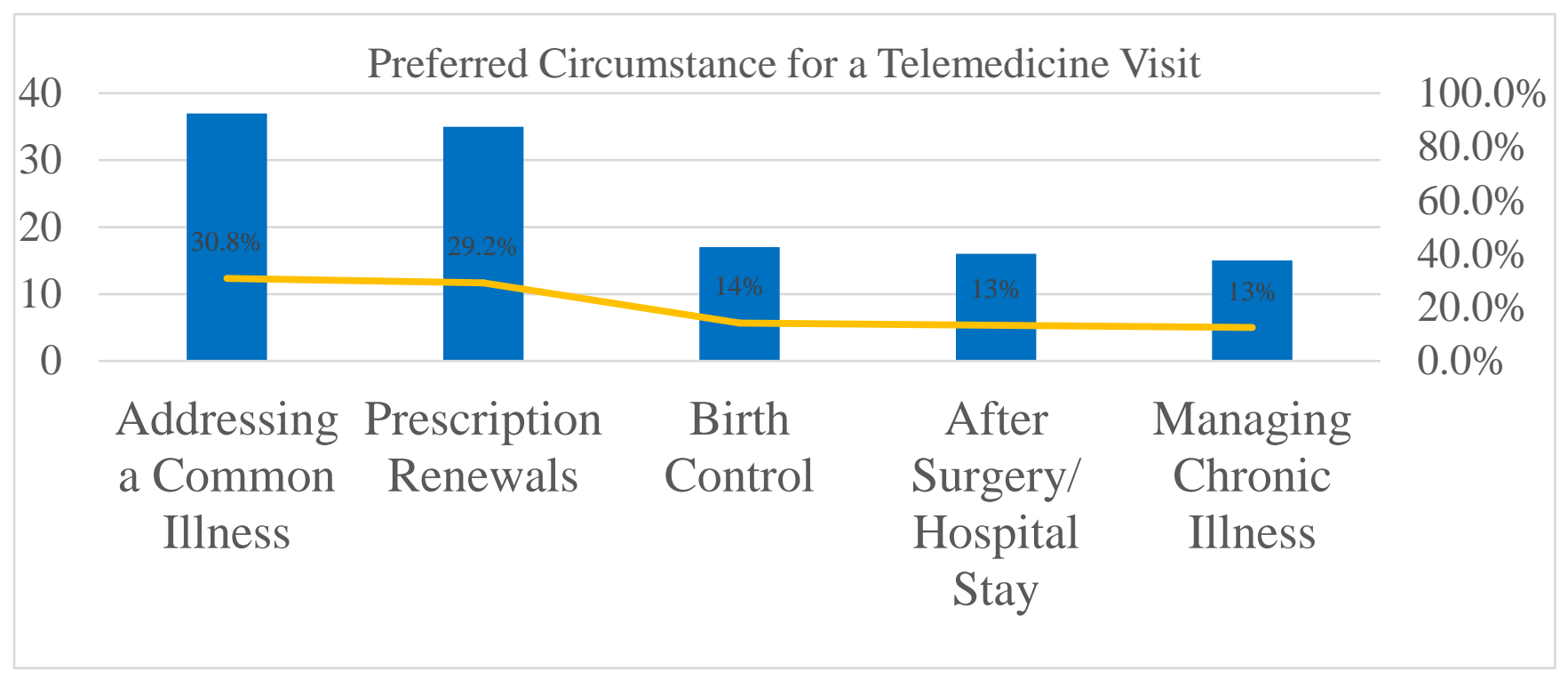

